\title{
Hemşirelik Öğrencilerinin Merhamet Düzeyi ve Empatik Eğilim Iliş̧kisi
}

\author{
Afitap Özdelikara ${ }^{1} \odot$, Serpil Babur ${ }^{2} \odot$
}

'Ondokuz Mayıs Üniversitesi Sağlık Bilimleri Fakültesi, İ̧ Hastalıkları Hemşireliği Anabilim Dalı, Samsun, Türkiye

${ }^{2}$ Ondokuz Mayıs Üniversitesi Sağlık Uygulama ve Araştırma Hastanesi, Dahiliye Yoğun Bakım Ünitesi, Samsun, Türkiye

Afitap Özdelikara, Dr. Öğr. Üyesi Serpil Babur, Uzm. Hemşire

\section{Illetişim:}

Dr. Öğr. Üyesi Afitap Özdelikara

Ondokuz Mayıs Üniversitesi Sağık Bilimleri Fakültesi, İç Hastalıkları Hemşireliği Anabilim Dalı, Samsun, Türkiye

Tel: +90362312 1919

E-Posta: afitapozdelikara@gmail.com

\section{ÖZET}

Amaç: Tanımlayıı tipteki bu araştırma; öğrenci hemşirelerin merhamet düzeylerini ve empatik eğilimlerini belirlemek amacıyla yapılmıştır.

Çalışma Planı: Araştırmanın evrenini, Ondokuz Mayıs Üniversitesi Sağılı Bilimleri Fakültesi Hemşirelik Bölümü öğrencileri ( $n=274$ ) oluşturmuştur. Veriler, 12 soruluk anket formu, Merhamet Ölçeği ve Empatik Eğilim Ölçeği ile 1 Nisan-1 Haziran 2017 tarihleri arasında toplanmıştır. Verilerin analizinde ortalama, yüzdelik hesaplamaları, Man Whitney U, Kruskal Wallis, korelasyon analizi kullanılmıştır.

Bulgular: Öğrencilerin yaş ortalaması $20,39 \pm 1,87, \% 79,6^{\prime}$ 's kadın, $\% 29,5^{\prime} \mathrm{i} 1$. sınıf olup, $\% 64,1^{\prime} i$ merhamet yorgunluğunu orta derecede yaşadıklarını, \%49,1'i empati yeteneğini orta derece olarak değerlendirmişlerdir. Öğrencilerin merhamet ölçeği puan ortalamaları $72,79 \pm 10,02$; empatik eğilim puan ortalamaları $68,34 \pm 8,21$ olarak belirlenmiştir. Merhamet yorgunluğu ölçek toplam puanı sorgulanan değişkenlere göre istatistiksel farklıık göstermezken, empatik eğilim ölçeği toplam puanının 'hastanın çektiği acıdan etkilenme' durumundan etkilendiği ve istatistiksel olarak farklılık gösterdiği belirlenmiştir $(p<0,05)$. Merhamet ölçeği toplam puanı ile empatik eğilim ölçeği toplam puanı arasında pozitif yönde anlamlı ilişki saptanmıştı.

Sonuç: Öğrencilerin merhamet ölçeği ve empatik eğilim ölçeği puan ortalamalarının orta düzeyde olduğu; merhamet ve empatik eğilim arasında birbirine paralel artış/azalma gösterdiği belirlenmiştir. öğrencilerde merhamet ve empatik eğilimin geliştirilmesi, merhamet yorgunluğu ve duygu bulaşmasının olumsuz etkilerine karşı ögrencilerin donanımlı hale getirilmesi önerilebilir.

Anahtar sözcükler: Hemşirelik, merhamet, empati, merhamet yorgunluğu

\section{DETERMINATION OF COMPASSION LEVELS AND EMPATHIC TENDENCY OF NURSING STUDENTS}

\section{ABSTRACT}

Objectives: The aim of this descriptive type of study was (OR: This descriptive type of study aimed) to determine the levels of compassion and the empathic tendency of nursing students.

Study Design: The study sample consisted of students of the Nursing Department of Health Sciences Faculty at Ondokuz Mayıs University. The data were collected from April 1 to June 1, 2017, with a 12-question questionnaire, the Compassion Scale and the Empathic Tendency Scale. Analysis of the data was (OR: Data analysis was) used in the mean, percentage calculations, MannWhitney $\mathrm{U}$ test, Kruskal-Wallis test and correlation analysis.

Results: The average age of students is $20.39 \pm 1.87,29.5 \%$ of students are in first grade, and $79.6 \%$ of them are females and $64.1 \%$ of students live the compassion tiredness on average, $49.1 \%$ of students' empathetic tendency is at the average level. Students' point average of compassion scale is $72.79 \pm 10.02$, empathetic tendency average point is determined as $68.34 \pm 8.21$. Compassion fatigue scale total score was not statistically different compared to the questioned variables, but it was determined that the total score of the empathic tendency scale was affected by the patient's suffering $(p<0.05)$. A positive correlation was found between the total score of the Compassion Scale and the total score of the empathic tendency scale.

Conclusions: Students' compassion scale's and empathetic tendency scale's point average is middle-level. Developing compassion and empathic tendency in the students, it can be suggested that the students are equipped with the negative effects of compassion fatigue and emotional transmission.

Keywords: Compassion, empathy, compassion fatigue, nursing 
$\mathbf{H}$ emşirelik, insanlarla sürekli zaman geçirilen ve insan ilişkilerinin çok yoğun olduğu bir yardım mesleğidir (1). Yardım etmede temel amaç; karşılıklı güvenin olduğu bir iletişim ve etkileşim içinde, bireyi bir bütün olarak tanımak, bireyin bakım gereksinimlerini tanımlamak ve sorunları ile daha etkin baş edebilir ve gereksinimlerini karşılayabilir hale gelmesini sağlamaktır (2). Insanlara yardım etme güdüsünü harekete geçiren sosyal duygulardan olan merhamet, empatinin ilk tetikleyicisidir. $(3,4)$. Empati, hemşirelik bakımının dolayısıyla yardım edici ilişkinin en temel bileşenidir (2).

Türk Dil Kurumu merhameti; "bir kimsenin veya bir başka canlının karşılaştığı kötü durumdan dolayı duyulan üzüntü, acıma" olarak tanımlamıştır (5). Merhamet, başka bireylerin acısını dindirme güdüsünü, acının kaynağın bulmayla ilgili bilişsel süreçleri, merhametli eylemlerde bulunmakla ilgili ise davranışsal süreçleri kapsar. Yani merhamet; istek, duygu, düşünce ve davranışların karışımı ile ortaya çıkar (6). Bir çalışmada merhametin, sevgi kavramı ile eşdeğer olduğundan, insanların sıkıntılı ve ihtiyaç duydukları zamanlarında onları desteklemeye yönelik, davranışsal, bilişsel ve duygusal bir davranış olduğundan bahsedilmiştir (7). Merhamet, hemşirelik bakımının içerisinde sıklıkla yer alması gereken kavramlardan biridir (8).

Merhamet yorgunluğu ise bir terim olarak ilk kez 1992 yllında hemşire Joinson tarafından, hemşirelerin hastalara bakım verirken yaşadıkları strese cevap olarak kendi duygularını devre dışı bırakıp hissettikleri öfke ve çaresizlik duygularını tanımlamak için bir hemşirelik dergisinde kullanılmıştır (9). Merhamet yorgunluğu, travmatik durumlara maruz kalan kişilere yardım etme sürecinin negatif etkisi olarak tanımlanabilir. Hemşireler; hastaların travma, acı ve ağrılarına merhamet göstermeleri, hastaların travmalarına maruz kalmaları nedeniyle merhamet yorgunluğunu çok fazla yaşayan bir meslek grubudur (10).

Tarihsel süreç boyunca empati, farklı boyutlar ve anlamlar katılarak tanımlanmıştır. Adler'e göre empati, başkasının gözleri ile görmek, başkasının kulağı ile duymak, başkasının kalbi ile hissetmektir (11). Genel bir ifade ile empati; bir kişinin kendisini karşısındakinin yerine koyarak olaylara onun bakış açısı ile bakması, o kişinin duygularını ve düşüncelerini doğru olarak anlaması, hissetmesi ve bu durumu ona iletmesi sürecidir $(1,12,13)$. Empatik eğilim ise bireyin empati yapabilme potansiyelidir $(1,12,13)$. Karşıdakinin duygularını anlama ve duygusal yaşantılarından etkilenme yeteneği, yardım etme isteği olarak belirtilmektedir (12). Rogers, empatik eğilimi sosyal duyarlılık olarak tanımlamıştır. Sosyal duyarlılığın bir kişilik özelliği olduğunu ve her insanda bulunmadığını, sosyal duyarlılığa sahip bireylerin daha fazla empatik olabileceklerini ve empatiyi kolayca öğrenebileceklerini belirtmiştir (11). Hemşirelerin; hastaları doğru ve tarafsız bir şekilde anlayabilmesi, gereksinimlerini belirleyebilmesi ve olumlu sonuçlar elde edebilmesi empati yeteneği ve eğilimi ile ilişkilendirilebilir $(1,14)$. Çünkü yardım edebilmek için bakım verdiğimiz bireye ulaşmamız, ona değer vermemiz, bireyi anlamaya çalışmamız, onunla ilgilenmemiz ve ona güvenmemiz önemlidir (2). Empatinin etkili kullanımı; hastanın durumuna ve gereksinimlerine uygun hemşirelik girişimlerinin planlanmasında faydalı olmasının yanında, hasta memnuniyetinin ve bakım kalitesinin artmasında da önemlidir (1). Hemşirelerin hastalarına yeterli bakım vermeleri ve onlara yardımcı olabilmeleri için empati becerilerinin istenilen düzeyde geliştirilmiş olması ve empatik eğilime sahip olmaları gerekmektedir (11). Günümüzde empatik beceri ve empatik eğilimin, hemşirelik eğitimi sürecinde geliştirilmesi mümkün bir beceri olduğu kabul edilmektedir (1). Bu nedenle empatik beceri ve empatik eğilim insanların bir kişilik özelliği olsa da bu gibi özelliklerin mesleki eğitim sırasında kazandırılması ve mesleki uygulamalarla da pekiştirilmesinin oldukça önemi bulunmaktadır $(1,11)$.

Tarihsel süreç içerisinde hemşireliğin temelinin; kadının anne şefkatinden kaynaklanan koruyucu ve bakım verici davranışlarına ya da zor durumda olan bireye, düşküne, çaresize dini ve vicdani duygular içinde yaklaşarak bakım, besleme ve iyileştirme girişimlerine dayanıyor olduğu (15) göz önünde bulundurulursa; şefkat gösterme anlamına gelen merhametin, öğrencilerin empatik eğilimlerinin üzerine etkisinin belirlenmesi gerekmektedir.

\section{Materyal ve metod}

\section{Araştırmanın tipi}

Tanımlayıcı nitelikteki araştırma 1 Nisan-1 Haziran 2017 tarihleri arasında XXXXXX Üniversitesi Sağlık Bilimleri Fakültesi Hemşirelik bölümü öğrencileri ile gerçekleştirilmiştir.

\section{Araştırmanın evreni ve örneklemi}

Araştırma evrenini XXXXXXX Üniversitesi Sağlık Bilimleri Fakültesi Hemşirelik Bölümü'nde öğrenim gören öğrenciler oluşturmaktadır. Araştırmada herhangi bir örneklem seçim yöntemine gidilmemiş, araştırmaya katılamaya gönüllü olan 274 (geri dönüş \%69) öğrenci ile araştırma gerçekleştirilmiştir. 


\section{Veri toplama araçları ve verilerin toplanması}

Verilerin toplanması ise literatür ışığında hazırlanan 12 soruluk anket formu, Merhamet Ölçeği (MÖ) ve Empatik Eğilim Ölçeği (EEÖ) kullanılmıştır.

Anket Formu: Sosyodemografik verilerin sorgulandığı 12 soru ve merhamet yorgunluğuna yönelik 5 soru bulunmaktadır.

Merhamet Ölçeği (MÖ): MÖ'nün orijinal versiyonu Pommier tarafından geliştirilmiştir. Ölçek 24 maddeden oluşmaktadır sevecenlik, umursamazlık, paylaşımların bilincinde olma, bağlantısızlık, bilinçli farkındalık ve ilişki kesme olmak üzere altı alt boyuttan oluşan ölçek, likert tipi beş uygunluk derecelendirmesine sahiptir. Bu alt boyutlara ait maddelerin faktör yükleri; sevecenlik alt boyutu için; 61-74, umursamazlık için; 56-69, paylaşımların bilincinde olma için; 54-83, bağlantısızlık için 51-73, bilinçli farkındalık için; 55-72 ve ilişki kesme için 58-68 arasında değişmektedir. İç tutarlık güvenirlik katsayıları alt boyutlar için; 57 ile 77 arasında değişmektedir (16).

Empatik Eğilim Ölçeği (EEÖ): Dökmen (1988) tarafından geliştirilen empatik eğilim ölçeğinin amacı, kişilerin günlük yaşamda empati kurma eğilimlerini değerlendirmektir. Likert türü bir ölçek olarak hazırlanan ve 20 maddeden oluşan Empatik Eğilim Ölçeğinin 8 maddesi $(3,6,7,8,11-$ $13,15)$ ters ifade edilmiştir. Bireylerden her bir maddenin yanındaki 1'den 5'e kadar olan sayılardan birini işaretleyerek, o maddedeki görüşe ne ölçüde katıldıklarını belirtmeleri istenmiştir. Bireylerin maddeleri okuduktan sonra işaretledikleri sayılar o maddeye ilişkin puanları oluşturmaktadır. Negatif yazıımış maddeler tersten puanlanmakta ve tamamen katılıyorum 1, hiç katılmıyorum ise 5 puan verilmektedir. Puanın yüksek olması, empatik eğilimin yüksek olduğu, düşük olması ise empatik eğilimin düşük olduğu anlamına gelmektedir. Test yarılama yöntemiyle ölçeğin tek ve çift maddelerinden alınan puanlar arasındaki korelasyon katsayısı 0,81'dir (17).

\section{Araştırmanın etiği}

Araştırmaya başlamadan önce XXXXXXX Üniversitesi Sosyal ve Beşeri Bilimler Etik Kurulu'ndan 17,04,2017 tarihli ve 2017-56 sayılı, Sağlık Bilimleri Fakültesi'nden yazııl; araştırmaya katılan öğrencilerden ise sözlü izin alınmıştır.

\section{Verilerin analizi}

Veriler IBM SPSS 21 (Statistical package for the social sciences-Demo Version 21 Chicago, IL, USA) paket programı kullanılarak değerlendirilmiştir. Verilerin normal dağılıma uygunluğu Shapiro Wilk testi ile incelenmiştir. Verilerin analizinde ortalama, yüzdelik hesaplamaları, Man Whitney $\mathrm{U}$, Kruskal Wallis ve korelasyon analizi kullanılmıştır.

\section{Bulgular}

Araştırmaya katılan öğrencilerin \%79,6'sinin kadın, \%99,6'sının bekar, \%29,6'sının birinci sınıf öğrencisi, $\% 77,9$ 'unun Anadolu-Fen lisesi mezunu olduğu belirlenmiştir. Öğrencilerin $\% 63,1$ 'inin bölümü isteyerek seçtiği, \%68,8'inin bölümden memnun olduğu, \%60,4'ünün hemşirelik hizmeti almadığı belirlenmiştir (Tablo 1 ). Öğrencilerin \%84,9'u hastanede diğer insanlardan duygu bulaşı yaşadığını, \%60,3'ü hastanın çektiği acıdan orta

\begin{tabular}{|c|c|c|}
\hline Sosyodemografik veriler & $N$ & $\%$ \\
\hline \multicolumn{3}{|l|}{ Cinsiyet } \\
\hline Kadın & 219 & 79,6 \\
\hline Erkek & 56 & 20,4 \\
\hline \multicolumn{3}{|l|}{ Medeni durum } \\
\hline Evli & 13 & 4,7 \\
\hline Bekar & 262 & 99,6 \\
\hline \multicolumn{3}{|l|}{ Sinif } \\
\hline 1 & 82 & 29,6 \\
\hline 2 & 79 & 28,8 \\
\hline 3 & 67 & 24,5 \\
\hline 4 & 47 & 17,2 \\
\hline \multicolumn{3}{|l|}{ Mezun olunan lise } \\
\hline Anadolu-fen & 215 & 77,9 \\
\hline Sağlık meslek & 20 & 7,4 \\
\hline Diğer & 40 & 14,7 \\
\hline \multicolumn{3}{|l|}{ Bölümü isteyerek seçme } \\
\hline Evet & 174 & 63,1 \\
\hline Hayır & 101 & 36,9 \\
\hline \multicolumn{3}{|l|}{ Bölümden memnun olma } \\
\hline Evet & 190 & 68,8 \\
\hline Hayır & 85 & 31,3 \\
\hline \multicolumn{3}{|l|}{ Hemşirelik hizmeti alma } \\
\hline Evet & 110 & 39,6 \\
\hline Hayır & 165 & 60,4 \\
\hline
\end{tabular}

düzeyde etkilendiği, \%55,3'ü acıyı hatırlattığı için eylemlerini sınırlamadıklarını bildirmiştir. Öğrencilerin \%64,1'i merhamet yorgunluğunu orta düzeyde algıladığını, $\% 49,1$ 'i empati becerisini orta düzeyde bulduğunu bildirmiştir (Tablo 2). 
Tablo 2. Öğrencilerin merhamet yorgunluğuna ilişkin verilerinin dağılımı

\begin{tabular}{lcc} 
Merhamet Yorgunluğuna Illişkin Sorular & N & $\%$ \\
\hline Hastanede duygu bulaşı yaşama durumu & & \\
Evet & 234 & 84,9 \\
Hayır & 41 & 15,1 \\
\hline Hastanın çektiği acıdan etkilenme düzeyi & 79 & 29 \\
Fazla & 167 & 60,3 \\
Orta & 29 & 10,7 \\
Hafif & & \\
\hline Acıyı hatırlattığı için eylemlerini sınırlama durumu & 122 & 44,7 \\
Evet & 153 & 55,3 \\
Hayır & & \\
\hline Algılanan merhamet yorgunluğu düzeyi & 38 & 13,9 \\
Hafif & 177 & 64,1 \\
Orta & 60 & 22 \\
Şiddetli & & \\
\hline Algılanan empati becerisi düzeyi & 131 & 48 \\
İyi & 136 & 49,1 \\
Orta & 8 & 2,9 \\
Kötü & & \\
& & \\
\end{tabular}

Öğrencilerin merhamet ölçeği puan ortalamaları $72,79 \pm 10,02$ olarak belirlenirken, alt boyutlarda en yüksek

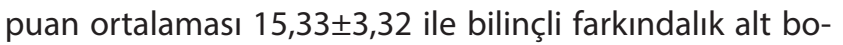
yutuna ait olmuştur. Bunu sırasıyla 15,19 $\pm 2,91$ ile sevecen-


9,15 $\pm 3,34$ ile umursamazlık ve 8,78 $\pm 3,30$ ile ilişki kesme alt boyutu takip etmiştir. Öğrencilerin empatik eğilimleri puan ortalaması $68,34 \pm 8,21$ olarak belirlenmiştir (Tablo 3 ).

Tablo 4'te Bazı değiş̧kenlere göre empatik eğilim ölçeği ve merhamet ölçeği alt boyut ortanca puan değerleri verilmiştir. Buna göre; kadın öğrencilerin sevecenlik, paylaşım,

\begin{tabular}{|c|c|c|c|}
\hline Ölçek ve Alt Boyutları & Minimum & Maximum & Ortalama \\
\hline Sevecenlik & 4,00 & 20,00 & $15,19 \pm 2,91$ \\
\hline Umursamazlık & 4,00 & 20,00 & $9,15 \pm 3,34$ \\
\hline Paylaşım & 5,00 & 20,00 & $14,80 \pm 2,93$ \\
\hline Bağlantısızıkk & 4,00 & 20,00 & $9,50 \pm 3,54$ \\
\hline Bilinçli Farkındalık & 6,00 & 20,00 & $15,33 \pm 3,32$ \\
\hline İlişki Kesme & 4,00 & 20,00 & $8,78 \pm 3,30$ \\
\hline Merhamet Öıçeği Toplam Puanı & 30,00 & 120,00 & $72,79 \pm 10,02$ \\
\hline Empatik Eğilim Ölçeği Toplam Puanı & 49,00 & 100,00 & $68,34 \pm 8,21$ \\
\hline
\end{tabular}

bilinçli farkındalık alt boyut ortanca değerleri ile empatik eğilim ölçeği ortanca puan değerleri yüksek bulunmuştur. Cinsiyet değişkeni ile sevecenlik, umursamazlık, paylaşım, bağlantısızlık ve bilinçli farkındalık alt boyutları arasındaki fark istatistiksel olarak anlamlı bulunmuştur $(p<0,05)$. Medeni durumuna göre bakıldığında, bekar öğrencilerin sevecenlik, paylaşım, bilinçli farkındalık ve empatik eğilim ölçeği puanlarının evli olanlara göre yüksek olduğu ve umursamazlık, bağlantısızlık alt boyutu ile medeni durum değişkeni arasındaki farkın istatistiksel olarak anlamlı olduğu belirlenmiştir $(p<0,05)$. Sınıf değişkeni ile sevecenlik, umursamazlık, paylaşım ve ilişki kesme alt boyutu arasındaki fark istatistiksel olarak anlamlı bulunmuştur $(p<0,05)$. Hastanede duygu bulaşı yaşadığını bildiren öğrencilerin sevecenlik, paylaşım, bilinçli farkındalık alt boyutu ve empatik eğilim ortanca puan değerleri yüksek bulunmuştur. Duygu bulaşı durumu ile umursamazlık, bağlantısızlık ve ilişki kesme alt boyutu arasındaki fark istatistiksel olarak anlamlı bulunmuştur $(p<0,05)$. Hastanın çektiği acıdan hafif etkilenen öğrencilerin sevecenlik alt boyutu dışında merhamet ölçeği ve alt boyutlarından aldıkları ortanca puan değerleri yüksek bulunurken, empatik eğilim ortanca puan değeri diğer gruplardan düşük bulunmuştur. Hastanın çektiği acıdan etkilenme durumu ile umursamazlık, ilişki kesme ve empatik eğilim ölçeği ortanca puan değeri arasındaki fark istatistiksel olarak anlamlı bulunmuştur $(p<0,05)$. Acıyı hatırlattığı için eylemlerini sınırlamadığını bildiren öğrencilerin umursamazlık, paylaşım ve empatik eğilim ortanca puan değeri dışındaki puan ortalamaları yüksek bulunmuştur $(p>0,05)$. Merhamet yorgunluğunu hafif düzeyde algıladığını bildiren öğrencilerin sevecenlik, paylaşım ve bilinçli farkındalık alt boyutları dışındaki ortanca puan ortalamaları diğer gruplardan yüksek olarak belirlenmiştir. Merhamet yorgunluğu ile sevecenlik, umursamazlık, bağlantısızlık, bilinçli farkındalık ve ilişki kesme alt boyut ortanca puanları arasındaki fark istatistiksel olarak anlamlı bulunmuştur $(p<0,05)$. Empati becerisini iyi olarak bildiren öğrencilerin sevecenlik, paylaşım, bilinçli farkındalık alt boyutları ve empatik eğilim ortanca puan değerleri diğer gruplardan yüksek bulunmuştur. Algılanan empati becerisi ile sevecenlik, umursamazlık, bağlantısızlık ve bilinçli farkındalık alt boyut puan ortalamaları arasındaki fark istatistiksel olarak anlamlı bulunmuştur $(p<0,05)$.

Tablo 5'de merhamet ölçeği alt boyutları ve empatik eğilim ölçeğine ilişkin korelasyon değerlerinin dağılımı verilmiştir. Buna göre; sevecenlik alt boyutu ile paylaşım, bilinçli farkındalık alt boyutları ve merhamet ölçeği toplam puanı arasında pozitif yönlü anlamlı ilişki belirlenirken, umursamazlık, bağlantısızlık ve ilişki kesme alt boyutları arasında 
Tablo 4. Bazı değişkenlere göre EEÖ ve MÖ alt boyutları ortanca puan değerlerinin dağlımı

\begin{tabular}{|c|c|c|c|c|c|c|c|c|}
\hline Değişkenler & Sevecenlik & Umursamazlık & Paylaşım & Bağlantısızlık & $\begin{array}{c}\text { Bilinçli } \\
\text { Farkındalık }\end{array}$ & İlişki Kesme & $\begin{array}{c}\text { Merhamet } \\
\text { Ölçeği }\end{array}$ & $\begin{array}{c}\text { Empati Eğilim } \\
\text { Ölçeği }\end{array}$ \\
\hline \multicolumn{9}{|l|}{ Cinsiyet } \\
\hline Kadın & $16(7-20)$ & $8(4-20)$ & $15(6-20)$ & $9(4-42)$ & $16(6-45)$ & $8(4-20)$ & $72(42-120)$ & $68(49-100)$ \\
\hline \multirow[t]{2}{*}{ Erkek } & $14(5-20)$ & $11(4-19)$ & $13(5-20)$ & $11(4-16)$ & $14(6-20)$ & $11(4-17)$ & $72,5(30-102)$ & 67 (53-90) \\
\hline & $\begin{array}{c}\text { MW-U: } 4335,5 \\
\text { p: } \mathbf{0 , 0 0 2}\end{array}$ & $\begin{array}{c}\text { MW-U: } 3748,5 \\
\text { p: } \mathbf{0 , 0 0 0}\end{array}$ & $\begin{array}{c}\text { MW-U: } 4431,0 \\
\text { p: } \mathbf{0 , 0 1 0}\end{array}$ & $\begin{array}{c}\text { MW-U: } 4029,0 \\
\text { p: } \mathbf{0 , 0 0 0}\end{array}$ & $\begin{array}{c}\text { MW-U: } 4032,0 \\
\text { p: } \mathbf{0 , 0 0 0}\end{array}$ & $\begin{array}{c}\text { MW-U: } 5071,0 \\
\text { p: } 0,487\end{array}$ & $\begin{array}{c}\text { MW-U: } 4158,5 \\
\text { p: } 0,132\end{array}$ & $\begin{array}{c}\text { MW-U: } 5071,0 \\
\text { p: } 0,487\end{array}$ \\
\hline \multicolumn{9}{|l|}{ Sinıf } \\
\hline 1 & $15(7-20)$ & $10(4-20)$ & $14(6-20)$ & $10(4-20)$ & $15(6-20)$ & $9(4-20)$ & $72(42-120)$ & $68(49-100)$ \\
\hline 2 & $16(10-20)$ & $8(4-19)$ & $16(7-20)$ & $8(4-16)$ & $16(12-45)$ & $8(4-17)$ & $72(52-112)$ & $68(50-88)$ \\
\hline 3 & $16(5-20)$ & $8(4-20)$ & $15(5-20)$ & $8,5(4-42)$ & $17(7-20)$ & $7(4-20)$ & $71,5(30-120)$ & $66(51-90)$ \\
\hline \multirow[t]{2}{*}{4} & $14(10-20)$ & $9,5(4-15)$ & $15(8-19)$ & $11(4-15)$ & $15(11-20)$ & $9(4-17)$ & $72(58-87)$ & $67,5(55-100)$ \\
\hline & $\begin{array}{c}\mathrm{KW}: 11,894 \\
\text { p: } \mathbf{0 , 0 0 8}\end{array}$ & $\begin{array}{l}\text { KW: } 14,946 \\
\text { p: } \mathbf{0 , 0 0 2}\end{array}$ & $\begin{array}{l}\mathrm{KW}: 8,053 \\
\mathbf{p :} \mathbf{0 , 0 4 5}\end{array}$ & $\begin{array}{c}\text { KW: } 7,627 \\
\text { p: } 0,054\end{array}$ & $\begin{array}{c}\mathrm{KW}: 7,649 \\
\mathrm{p}: 0,054\end{array}$ & $\begin{array}{c}\mathrm{KW}: 9,366 \\
\mathbf{p :} \mathbf{0 , 0 2 5}\end{array}$ & $\begin{array}{c}\mathrm{KW}: 3,398 \\
\mathrm{p}: 0,334\end{array}$ & $\begin{array}{c}\mathrm{KW}: 2,301 \\
\mathrm{p}: 0,512\end{array}$ \\
\hline \multicolumn{9}{|c|}{ Hastanede duygu bulaşı yaşama durumu } \\
\hline Evet & $15,2(5-20)$ & $8,9(4-20)$ & $14,8(5-20)$ & $9,3(4-42)$ & $15,4(6-45)$ & $8,4(4-20)$ & $72,2(30-120)$ & $68,6(50-100)$ \\
\hline \multirow[t]{2}{*}{ Hayır } & $14,7(11-20)$ & $10,4(4-20)$ & $14,6(7-20)$ & $10,6(4-20)$ & $14,7(9-20)$ & $10,7(5-20)$ & $75,7(63-120)$ & $66,9(49-85)$ \\
\hline & $\begin{array}{c}\text { MWU: } 4029,0 \\
\text { p: } 0,181\end{array}$ & $\begin{array}{c}\text { MWU: } 3428,0 \\
\text { p: } \mathbf{0 , 0 1 3}\end{array}$ & $\begin{array}{c}\text { MWU: } 4343,5 \\
\text { p: } 0,610\end{array}$ & $\begin{array}{c}\text { MWU: } 3285,0 \\
\text { p: } \mathbf{0 , 0 0 6}\end{array}$ & $\begin{array}{c}\text { MWU: } 3967,0 \\
\text { p: } 0,189\end{array}$ & $\begin{array}{c}\text { MWU: } 2869,0 \\
\text { p: } \mathbf{0 , 0 0 0}\end{array}$ & $\begin{array}{l}\text { MWU: } 3288,5 \\
\text { p: } 0,102\end{array}$ & $\begin{array}{c}\text { MWU: } 3672,5 \\
\text { p: } 0,282\end{array}$ \\
\hline \multicolumn{9}{|c|}{ Hastanın çektiği acıdan etkilenme düzeyi } \\
\hline Fazla & $15,2(5-20)$ & $9(4-20)$ & $15(5-20)$ & $9,2(4-20)$ & $15,4(6-20)$ & $8,3(4-20)$ & $72,1(30-120)$ & $69,8(53-100)$ \\
\hline Orta & $15,3(7-20)$ & $8,9(4-18)$ & $14,6(6-20)$ & $9,3(4-42)$ & $15,1(6-20)$ & $8,6(4-19)$ & $72,1(42-110)$ & $68,22(49-92)$ \\
\hline \multirow[t]{2}{*}{ Hafif } & $14,2(10-20)$ & $10,8(4-20)$ & $15,1(10-20)$ & $10,7(5-20)$ & $15,8(10-45)$ & $10,6(4-20)$ & $77,4(62-120)$ & $65,1(54-79)$ \\
\hline & $\begin{array}{c}\mathrm{KW}: 4,659 \\
\mathrm{p}: 0,097\end{array}$ & $\begin{array}{c}\mathrm{KW}: 6,379 \\
\mathbf{p :} \mathbf{0 , 0 4 1}\end{array}$ & $\begin{array}{c}\mathrm{KW}: 1,683 \\
\mathrm{p}: 0,431\end{array}$ & $\begin{array}{c}\mathrm{KW}: 4,935 \\
\mathrm{p}: 0,085\end{array}$ & $\begin{array}{c}\mathrm{KW}: .941 \\
\mathrm{p}: 0,625\end{array}$ & $\begin{array}{c}\mathrm{KW}: 9,511 \\
\mathbf{p :} \mathbf{0 , 0 0 9}\end{array}$ & $\begin{array}{c}\mathrm{KW}: 2,228 \\
\mathrm{p}: 0,328\end{array}$ & $\begin{array}{c}\mathrm{KW}: 6,473 \\
\mathbf{p :} \mathbf{0 , 0 3 9}\end{array}$ \\
\hline \multicolumn{9}{|c|}{ Acıyı hatırlattığı için eylemlerini sınırlama durumu } \\
\hline Evet & $15,2(5-20)$ & $8,9(4-20)$ & $14,8(5-20)$ & $9,3(4-42)$ & $15,4(6-45)$ & $8,4(4-20)$ & $72,2(30-120)$ & $68,6(50-100)$ \\
\hline \multirow[t]{2}{*}{ Hayır } & $14,7(11-20)$ & $10,4(4-20)$ & $14,6(7-20)$ & $10,6(4-20)$ & $14,7(9-20)$ & $10,7(5-20)$ & $75,7(63-120)$ & $66,9(49-85)$ \\
\hline & $\begin{array}{c}\text { MWU: } 4029,0 \\
\text { p: } 0,181\end{array}$ & $\begin{array}{l}\text { MWU: } 3428,0 \\
\text { p: } \mathbf{0 . ~} 013\end{array}$ & $\begin{array}{c}\text { MWU: } 4343,5 \\
\text { p: } 0,610\end{array}$ & $\begin{array}{l}\text { MWU: } 3285,0 \\
\text { p: } \mathbf{0 , 0 0 6}\end{array}$ & $\begin{array}{c}\text { MWU: } 3967,0 \\
\text { p: } 0,189\end{array}$ & $\begin{array}{c}\text { MWU: } 2869,0 \\
\text { p: } \mathbf{0 , 0 0 0}\end{array}$ & $\begin{array}{l}\text { MWU: } 3288,5 \\
\text { p: } 0,102\end{array}$ & $\begin{array}{c}\text { MWU: } 3672,5 \\
\text { p: } 0,282\end{array}$ \\
\hline \multicolumn{9}{|c|}{ Algılanan merhamet yorgunluğunu } \\
\hline Hafif & $14,5(5-20)$ & $11,3(4-20)$ & $14(5-20)$ & $11,1(4-20)$ & $14,4(7-20)$ & $10,9(4-20)$ & $76,3(30-120)$ & $69,7(54-100)$ \\
\hline Orta & $15,1(7-20)$ & $8,8(4-18)$ & $14,8(6-20)$ & $9,3(4-42)$ & $15,4(6-45)$ & $8,5(4-19)$ & $72,2(42-112)$ & $67,9(50-92)$ \\
\hline \multirow[t]{2}{*}{ Şiddetli } & $15,7(8-20)$ & $8,7(4-16)$ & $15(8-20)$ & $8,9(4-15)$ & $15,6(6-20)$ & $8,1(4-15)$ & $72,2(52-93)$ & $68,7(49-83)$ \\
\hline & $\begin{array}{c}\mathrm{KW}: 9,047 \\
\mathbf{p :} \mathbf{0 , 0 1 1}\end{array}$ & $\begin{array}{c}\mathrm{KW}: 21,438 \\
\mathbf{p :} \mathbf{0}, \mathbf{0 0 0}\end{array}$ & $\begin{array}{c}\mathrm{KW}: 5,930 \\
\mathrm{p}: 0,052\end{array}$ & $\begin{array}{c}K W: 29,882 \\
\text { p: } \mathbf{0 . 0 0 0}\end{array}$ & $\begin{array}{c}K W: 14,898 \\
\text { p: } \mathbf{0 .} 001\end{array}$ & $\begin{array}{c}\text { KW: } 16,926 \\
\text { p: } \mathbf{0 .} \mathbf{0 0 0}\end{array}$ & $\begin{array}{l}\mathrm{KW}: 3,503 \\
\mathrm{p}: 0.174\end{array}$ & $\begin{array}{l}\text { KW: } 1,108 \\
\text { p: } 0.575\end{array}$ \\
\hline \multicolumn{9}{|c|}{ Algılanan empati becerisi } \\
\hline İyi & $15,7(7-20)$ & $8,2(4-20)$ & $15,2(8-20)$ & $8,7(4-42)$ & $15,8(6-20)$ & $8(4-20)$ & $71,9(42-120)$ & $68,9(50-100)$ \\
\hline Orta & $14,6(5-20)$ & $9,8(4-18)$ & $14,3(5-20)$ & $10(4-19)$ & $14,8(6-45)$ & $9,2(4-20)$ & $72,9(30-112)$ & $67,8(49-92)$ \\
\hline \multirow[t]{2}{*}{ Kötü } & $14,6(10-20)$ & $12,8(7-20)$ & $15(11-20)$ & $13,5(10-20)$ & $14,5(10-20)$ & $12,6(9-20)$ & $83,1(63-120)$ & $68,2(60-79)$ \\
\hline & $\begin{array}{c}K W: 9,047 \\
\text { p: } \mathbf{0 , 0 1 1}\end{array}$ & $\begin{array}{c}K W: 21,438 \\
\text { p: } \mathbf{0 , 0 0 0}\end{array}$ & $\begin{array}{c}\mathrm{KW}: 5,930 \\
\mathrm{p}: 0,052\end{array}$ & $\begin{array}{c}K W: 29,882 \\
\text { p: } \mathbf{0 , 0 0 0}\end{array}$ & $\begin{array}{c}\text { KW: } 14,898 \\
\text { p: } \mathbf{0 , 0 0 1}\end{array}$ & $\begin{array}{c}\mathrm{KW}: 0,785 \\
\mathrm{p}: 0,675\end{array}$ & $\begin{array}{c}\mathrm{KW}: 3,490 \\
\mathrm{p}: 0,175\end{array}$ & $\begin{array}{c}\mathrm{KW}: 0,785 \\
\mathrm{p}: 0,675\end{array}$ \\
\hline
\end{tabular}


Tablo 5. MÖ alt boyutları ve EEÖ korelasyon değerlerinin dağılımı

\begin{tabular}{|c|c|c|c|c|c|c|c|}
\hline & Sevecenlik & Umursamazlık & Paylaşım & Bağlantısızlık & $\begin{array}{c}\text { Bilinçli } \\
\text { Farkındalık }\end{array}$ & İlişki Kesme & $\begin{array}{l}\text { Merhamet Ölçeği } \\
\text { Toplam Puanı }\end{array}$ \\
\hline Umursamazlık & $\begin{array}{l}-0,438 \\
0,000\end{array}$ & & & & & & \\
\hline Paylaşım & $\begin{array}{l}0,536 \\
0,000\end{array}$ & $\begin{array}{l}-0,335 \\
0,000\end{array}$ & & & & & \\
\hline Bağlantısızlık & $\begin{array}{c}-0,433 \\
0,000\end{array}$ & $\begin{array}{l}0,778 \\
0,000\end{array}$ & $\begin{array}{c}-0,303 \\
0,000 \\
\end{array}$ & & & & \\
\hline Bilinçli Farkındalık & $\begin{array}{l}0,750 \\
0,000\end{array}$ & $\begin{array}{l}-0,437 \\
0,000\end{array}$ & $\begin{array}{l}0,668 \\
0,000\end{array}$ & $\begin{array}{c}-0,416 \\
0,000\end{array}$ & & & \\
\hline İlişki Kesme & $\begin{array}{c}-0,499 \\
0,000\end{array}$ & $\begin{array}{l}0,809 \\
0,000\end{array}$ & $\begin{array}{c}-0,334 \\
0,000\end{array}$ & $\begin{array}{l}0,800 \\
0,000\end{array}$ & $\begin{array}{l}-0,431 \\
0,000\end{array}$ & & \\
\hline $\begin{array}{l}\text { Merhamet Ölçeği } \\
\text { Toplam Puanı }\end{array}$ & $\begin{array}{l}0,202 \\
0,002\end{array}$ & $\begin{array}{l}0,536 \\
0,000\end{array}$ & $\begin{array}{l}0,393 \\
0,000\end{array}$ & $\begin{array}{l}0,526 \\
0,000\end{array}$ & $\begin{array}{l}0,298 \\
0,000\end{array}$ & $\begin{array}{l}0,533 \\
0,000\end{array}$ & \\
\hline $\begin{array}{l}\text { Empatik Eğilim Ölçeği } \\
\text { Toplam Puanı }\end{array}$ & $\begin{array}{l}0,322 \\
0,000\end{array}$ & $\begin{array}{l}0,053 \\
0,399\end{array}$ & $\begin{array}{l}0,283 \\
0,000\end{array}$ & $\begin{array}{c}-0,004 \\
0,948\end{array}$ & $\begin{array}{l}0,291 \\
0,000\end{array}$ & $\begin{array}{l}-0,010 \\
0,875\end{array}$ & $\begin{array}{l}0,353 \\
0,000\end{array}$ \\
\hline
\end{tabular}

negatif yönlü istatistiksel olarak anlamlı ilişki bulunmaktadır $(p<0,05)$. Umursamazlık alt boyutu ile bağlantısızlık, ilişki kesme ve merhamet ölçeği toplam puanı arasında pozitif yönde, paylaşım ve bilinçli farkındalık alt boyutları ile negatif yönde istatistiksel olarak anlamlı ilişki bulunmaktadır $(p<0,05)$. Paylaşım alt boyutu ile bilinçli farkındalık ve merhamet ölçeği toplam puanı arasında pozitif yönde, bağlantısızlık, ilişki kesme alt boyutları arasında negatif yönde istatistiksel olarak anlamlı ilişki bulunmaktadır $(p<0,05)$. Bağlantısızlık alt boyutu ile ilişki kesme ve merhamet ölçeği toplam puanı arasında pozitif yönde, bilinçli farkındalık alt boyutu arasında negatif yönde istatistiksel olarak anlamlı ilişki bulunmaktadır $(p<0,05)$. Bilinçli farkındalık alt boyutu ile merhamet ölçeği toplam puanı arasında pozitif yönde, ilişki kesme alt boyutu arasında negatif yönde anlamlı ilişki bulunurken, ilişki kesme alt boyutu ile merhamet ölçeği toplam puanı arasında pozitif yönde istatistiksel olarak anlamlı ilişki bulunmaktadır $(p<0,05)$.

Empatik eğilim ölçeği toplam puanı korelasyonuna bakıldığında, umursamazlık, bağlantısızlık ve ilişki kesme alt boyutları dışında diğer alt boyutlar ile empatik eğilim ölçeği toplam puanı arasında pozitif yönde istatistiksel olarak anlamlı ilişki belirlenmiştir $(p<0,05)$. Merhamet ölçeği toplam puanı ile empatik eğilim ölçeği toplam puanı arasında pozitif yönde istatistiksel olarak anlamlı ilişki saptanmıştır $(p<0,05)$.

\section{Tartışma}

Araştırma sonucunda öğrencilerin merhamet ölçeği puan ortalaması $72,79 \pm 10,02$ olarak belirlenmiştir. Dolayısıyla öğrencilerin merhamet seviyeleri orta düzeydedir. En yüksek puan ortalaması bilinçli farkındalık alt boyutuna aitken en düşük puan ortalamasının ilişki kesme alt boyutuna ait olduğu belirlenmiştir. Çingöl ve arkadaşlarının çalışmasında öğrencilerin merhamet düzeyleri yüksek bulunmuş ve en yüksek puan ortalamasına sahip alt boyutun sevecenlik, en düşük puan ortalamasına sahip alt boyutun ise ilişki kesme olduğu bildirilmiştir (18). Sağlık profesyonelleri ile yapılan araştırmada özellikle sevecenlik alt boyutunda hemşirelerin ortalamanın üzerinde puan aldığı bildirilmiştir (19). Merhamet düzeyi ve alt boyutlarını etkileyen önemli faktörlerden biri uzamış maruziyettir. Uzamış maruziyet, uzamış bir zaman süresince acı çekenin bakımı için devamIı olarak sorumluluk alma hissidir. Araştırma örnekleminin çoğunluğunu $(\% 58,4)$ birinci ve ikinci sınıf öğrencileri oluşturmaktadır. Bu grup öğrencilerin diğer sınıflara göre hasta ile etkileşimi ve maruziyeti sınırlı düzeydedir. Dolayısı ile hastaya daha kısa süreli bakım veren öğrencilerin sonucu bu yönde etkilediği düşünülmüştür. Öğrencilerin empatik eğilim puan ortalamaları $68,34 \pm 8,21$ olarak belirlenmiştir. Ölçekten alınabilecek puanın 20-100 arasında olduğu düşünüldüğünde empatik eğilim düzeyi orta düzeydedir. Karaca ve arkadaşlarının çalışmasında empatik eğilim puan ortalaması $68,45 \pm 6,81$, Arpacı ve Özmen'in çalışmasında $69,94 \pm 8,44$, Özcan'ın hemşirelerle yaptığı çalışmasında $65,95 \pm 10,66$ olarak belirlenmiştir $(13,20,21)$. Araştırma sonucu literatür ile paralellik göstermektedir (Tablo 3).

Öğrencilerin sosyodemografik değişkenlere göre merhamet ölçeği puanlarına bakıldığında; merhamet ölçeği toplam puanı ile cinsiyet değişkeni arasındaki fark istatistiksel olarak anlamlı bulunmamıştır ( $p>0,05$ ) (Tablo 4). Literatürde merhametin cinsiyet değişkeninden etkilendiğini bildiren 
çalışmalar mevcuttur $(18,22)$. Empatik eğilimin cinsiyet değişkeninden etkilenmemesine karşın kadın öğrencilerde empatik eğilim düzeyinin daha yüksek olduğu belirlenmiştir. Arpacı ve Özmen'in çalışmasında da cinsiyete göre empatik eğilim puanında anlamlı değişiklik gözlenmemiştir (20). Kadınların iletişim yeteneklerinin ve duygusal zekâlarının erkeklerden daha iyi olduğu ve şefkat ve acıma hissi gibi duygularının daha belirgin olduğu ve toplumsal olarak üstlendikleri rollerin empatik eğilimi arttırdığı bildirilmiştir (23). Bu durumun sonucu etkilediği düşünülmüştür.

Sınıf değişkeninin merhamet ölçeği toplam puanını etkilemediği belirlenmiştir ( $p>0,05)$ (Tablo 4). Çingöl'ün çalışmasında bizim sonucumuza benzer şekilde merhamet ölçeği ile sınıf değişkeni arasında anlamlılık olmadığı belirlenmiştir (18). Klinik ortam ile merhamet yorgunluğu ve tükenmişlik arasında bir bağlantı olduğu ve hemşirelik eğitimi sırasında oluşan klinik maruziyetin bu kavramlar adına risk oluşturduğu bildirilmektedir $(24,25)$. Araştırmamız sonucunun öğrencilerin sınıflarına göre bulundukları kliniklerin ve bakım gereksinimlerinin çeşitliliği nedeniyle oluşabileceği düşünülmüştür. Öğrencilerin empatik eğilim puanları ile sınıf değişkeni arasındaki fark istatistiksel olarak anlamlı bulunmamıştır $(p>0,05)$ (Tablo 4). Birinci ve dördüncü sınıf öğrencilerinin karşılaştırıldığı bir diğer çalışmada öğrencilerin empatik düzeyleri ve sınıf değişkeni arasında anlamlı farkın olmadığı bildirilmiştir (26). Ebelik öğrencileri ile yapılan bir başka çalışmada da bizim sonucumuza benzer şekilde sınıf değişkeni ile empatik eğilim düzeyi arasında anlamlı fark bulunmamıştır (27). Araştırmamız sonucu literatür ile uyumludur.

Hastanede duygu bulaşı yaşama ve hastanın çektiği acıdan etkilenme düzeyi ile merhamet ölçeği toplam puanı arasında istatistiksel olarak anlamlı fark bulunmamıştır ( $p>0,05)$ (Tablo 4). Empatik eğilim düzeyine bakıldığında istatistiksel olarak anlamlılık olmamasına karşın hastanede duygu bulaşı yaşayan öğrencilerin empatik eğilimleri yüksek bulunmuştur ( $p>0,05)$. Hastanın çektiği acıdan etkilenme düzeyini fazla olarak bildiren öğrencilerin empatik eğilimleri yüksek ve aradaki fark istatistiksel olarak anlamlı bulunmuştur $(p<0,05)$ (Tablo 4). Duygu bulaşması farkında olunmadan ruh halinin etkileşimlerden dolayı gelişebilmekte ve hemşirelerin çoğunluğu hastaların duygularının kendilerine bulaştığını bildirmektedirler $(28,29,30)$. Dolayısıyla duygu bulaşı yaşayan bireylerin empatik eğilimlerinin yüksek olması beklenen sonuçlardandır.

Merhamet ölçeği toplam puanı ve empatik eğilim ölçeği toplam puanı ile acıyı hatırlattığı için eylemlerini sınırlama durumu arasındaki fark istatistiksel olarak anlamlı bulunmamıştır $(p>0,05)$. Hastaya yönelik empatik tepki sonrasında birey kendini bu duygudan ayrıştıramazsa merhamet stresi yaşayabilmektedir (31). Dolayısıyla merhamet ölçeği ve empatik eğilim ölçeği toplam puanının, acıyı hatırlattığı için eylemlerini sınırlama durumundan etkilenmemesi, öğrencinin hastanın acı ile ilgili yaşantısından kendini ayrıştırabilme yeteneği ile ilgili olduğu söylenebilir.

Algılanan merhamet yorgunluğu ve empati becerisi ile merhamet ölçeği ve empatik eğilim arasındaki fark istatistiksel olarak anlamsız bulunmuştur ( $p>0,05)$ (Tablo 4). Hafif düzeyde merhamet yorgunluğu yaşayan öğrencilerde merhamet ölçeği ve empatik eğilim ölçeği puanlarının yüksek olması dikkat çekicidir. Literatürde merhamet yorgunluğunun uygunsuz karar vermeden, objektif olamamaya kadar bir çok alanda bireyi etkilediği, ayrıca kişi de empati kaybına ya da empati dengesini sürdürememe durumunu oluşturduğu bildirilmektedir (32). Merhamet yorgunluğunu hafif olarak algılayan öğrencilerin merhamet ve empatik eğilim düzeylerinin yüksek bulunmasının bunun bir sonucu olduğu düşünülmüştür.

Öğrencilerin merhamet ölçeği ve empatik eğilim düzeyleri arasındaki ilişkiye bakıldığında empatik eğilim ölçeği ile merhamet ölçeği, sevecenlik, paylaşım ve bilinçli farkındalık alt boyutları arasında pozitif yönde anlamlı ilişki saptanmıştır $(p<0,05)$ (Tablo 5). Merhametin felsefesine bakıldığında; en genel anlamıyla yaşam karşıtı ve acıyı artıran, acının yaratıcı tarafını kurutan bir içgüdü olarak düşünülmesi gerektiği bildirilmektedir. Merhamet, sayesinde başkasının acısının doğrudan kişinin kendi acısı olarak hissedileceğine vurgu yapılmaktadır. Bu güdü sayesinde, sevgi, adalet gibi değerler korunabilir. Felsefi yaklaşım ile bakıldığında merhamet ve empatik eğilim düzeylerinin paralel ilişkisi beklenen sonuçlardan biridir (33). Bu bilgiler ışığında empatinin başkasının penceresinden bakabilmek, merhametin ise başkasının acı veren duygusu için yardım arayışında olmakla ilişkilendirilmesi gerektiği açıktır. Dolayısıyla kendini bir başkasının yerine koymaya ilişkin eğiliminin olmasının altında ısdırabı dindirmeye yönelik yardım etme arzusu yani merhameti nedeniyle olduğu söylenebilir.

\section{Sonuç ve öneriler}

Araştırma sonucunda öğrencilerin merhamet ölçeği ve empatik eğilim ölçeği puan ortalamalarının orta düzeyde olduğu belirlenmiştir. Merhamet ölçeği alt boyutlarından bilinçli farkındalık alt boyutu en yüksek puan ortalamasına sahipken umursamazlık alt boyutu en düşük puan ortalamasına sahip alt boyut olmuştur. 
Bu sonuçlar doğrultusunda; öğrencilerde merhamet ve empatik eğilimin geliştirilmesi aynı zamanda merhamet yorgunluğu ve duygu bulaşmasının olumsuz etkilerine karşı öğrencilerin daha donanımlı hale getirilmesi önerilebilir. Bu amaçla merhamet yorgunluğu ve duygu bulaşının oluşturabileceği uyumsuzluk, isteksizlik vb. durumların fark edilmesi son derece önemlidir. Öğretim

\section{Kaynaklar}

1. Uncu F, Açık Y, Deveci SE, Çelebi E, Oğuzöncül AF, Ulaş B. Sağlık Yüksekokulunda Öğrenim Gören Hemşirelik Öğrencilerinin Empatik Eğilim ve Empatik Beceri Düzeylerinin Belirlenmesi. Yıldırım Beyazıt Üniversitesi Sağlık Bilimleri Fakültesi Hemşirelik E-Derg 2015;3.

2. Akgün Şahin Z, Kardaş Özdemir F. Hemşirelerin İletişim ve Empati Beceri Düzeylerinin Belirlenmesi. G. O. P. Taksim E. A. H. JAREN 2015;1:11-7. [CrossRef]

3. Goetz JL, Keltner D, Simon-Thomas E. Compassion: An Evolutionary Analysis and Empirical Review. Psychol Bull 2010;136:351-74. [CrossRef]

4. Palgi S, Klein E, Shamay-Tsoory GS. Intranasal Administration of Oxytocin Increases Compassion Toward Women. Soc Cogn Affect Neurosci 2015;10:311-17. [CrossRef]

5. Türk Dil Kurumu 2018. http://www.tdk.gov.tr

6. Gilbert P. Compassion And Cruelty: A Biopsychosocial Approach. In: Gilbert P, editor. Compassion: Conceptualisations, Research and Use in Psychotherapy. London, England: Routledge; 2005. p.9-74.

7. Sprecher S, Fehr B. Compassionate Love For Close Others And Humanity. Journal of Social and Personal Relationships 2005;22:62951. [CrossRef]

8. Bloomberg K, Griffiths P, Wengström Y, May C, Bridges J. Interventions For Compassionate Nursing Care: A Systematic Review. Int J Nurs Stud 2016;62:137-55. [CrossRef]

9. Joinson C. Coping With Compassion Fatigue. Nursing 1992;22:11821. [CrossRef]

10. Dikmen Y, Aydın Y. Hemşirelerde Merhamet Yorgunluğu: Ne? Nasıl? Ne Yapmalı? Compassion Fatıgue In Nurses: What? How? What To Do? J Hum Rhythm 2016;2:13-21. https://dergipark.org.tr/en/ download/article-file/566343

11. Öz F. Son Sınıf Hemşirelik Öğrencilerinin Empatik Eğilimleri, Empatik Becerileri ile Akademik Başarıları Arasındaki İlişki. Cumhuriyet Üniversitesi Hemşirelik Yüksekokulu Derg 1988;2:32-8. http:// eskidergi.cumhuriyet.edu.tr/makale/562.pdf

12. Avcı D, Aydın D, Özbaşaran F. Hemşirelik Öğrencilerinde EmpatiÖzgecilik İlişkisi ve Özgeci Davranışın Bazı Değişkenler Açısından İncelenmesi. Balıkesir Sağlık Bil Derg 2013;2:108-13. https:// dergipark.org.tr/en/download/article-file/521084

13. Karaca A, Açıkgöz F, Akkuş D. Eğitim ile Empatik Beceri ve Empatik Eğilim Geliştirilebilir mi? Bir Sağlık Yüksekokulu Örneği. Acıbadem Üniversitesi Sağlık Bil Derg 2013;4:118-122. http://acibadem.dergisi. org/uploads/pdf/pdf_AUD_192.pdf

14. Arifoğlu B, Razı SG. Birinci Sınıf Hemşirelik Öğrencilerinin Empati ve İletişim Becerileriyle İletişim Yönetimi Dersi Akademik Başarı Puanı Arasındaki İlişki. DEUHYO ED 2011;4:7-11. http://acikerisim.deu.edu. tr:8080/xmlui/bitstream/handle/20.500.12397/4576/7-11_arifoglu. pdf? sequence $=1$ \&isAllowed $=y$

15. Turan N, ÖztürkA, Kaya H, AtabekAştıT.Toplumsal Cinsiyet ve Hemşirelik. Maltepe Üniversitesi Hemşirelik Bilim ve Sanatı Derg 2011;4:167-73. http://hemsirelik.maltepe.edu.tr/dergiler/nisan/167-173.pdf

16. Pommier EA. The Compassion Scale. Dissertation Abstracts International Section. Hum Soc Sci 2011;72:11-74.

17. Dökmen Ü. Empatinin Yeni Bir Modele Dayanılarak Ölçülmesi ve Psikodrama İle Geliştirilmesi. Ankara Üniversitesi Eğitim Bilimleri Fakültesi Derg 1988;21:155-190. [CrossRef] elemanın özellikle empatik eğilim becerisi yüksek olduğunu düşündüğü öğrenciler için bu amaçla gözlem yapması önerilmektedir. Ayrıca öğrencinin hazır oluşluluğu göz önünde bulundurularak, eğitim dönemleri ile uyumlu biçimde kliniklere yönlendirilmesi zamansız yaşanacak merhamet yorgunluğu ve yıkıcı etkilerini önleyecektir.

18. Çingöl N, Çelebi E, Zengin S, Karakaş M. Bir Sağlık Yüksekokulu Hemşirelik Bölümü Öğrencilerinin Merhamet Düzeylerinin İncelenmesi. Klinik Psikiyatri Derg 2018;21:61-7. [CrossRef]

19. Polat NF, Erdem R. Merhamet Yorgunluğu Düzeyinin Çalışma Yaşam Kalitesi İle İlişkisi: Sağlık Profesyonelleri Örneği. Süleyman Demirel Üniversitesi Sosyal Bilimler Enstitüsü Derg 2017;1:291-312. https:// dergipark.org.tr/en/download/article-file/520634

20. Arpacı P, Özmen D. Hemşirelik Öğrencilerinin Özgecilik ve Empatik Eğilim Düzeyleri ve Aralarındaki İlişki. Hemşirelikte Eğitim ve Araştırma Derg 2014;11:51-57. https://www.journalagent.com/ kuhead/pdfs/KUHEAD_11_3_51_57.pdf

21. Özcan H. Hemşirelerin Empatik Eğilim ve Empatik Becerileri: Gümüşhane Örneği. Gümüşhane Üniversitesi Sağlık Bil Derg 2012;1:60-68. https://dergipark.org.tr/en/download/ article-file/84328

22. Salazar LR. The Relationship Between Compassion, Interpersonal Communication Apprehension, Narcissism and Verbal Aggressiveness. J Happiness Well-Being 2016;4:1-14.

23. Dizer B, İyigün E. Yoğun Bakım Hemşirelerinde Empatik Eğilim Düzeyleri ve Etkileyen Faktörler. Atatürk Üniversitesi Hemşirelik Yüksekokulu Derg 2009;12:9-18. https://dergipark.org.tr/en/ download/article-file/29443

24. Ralph E, Walker K, Wimmer R. Practicum And Clinical Experiences: Postpracticum Students' Views. J Nurs Educ 2009;48:434-40. [CrossRef]

25. Melincavage SM. Student Nurses' Experiences of Anxiety in The Clinical Setting. Nurs Educ Today 2011:31:785-9. [CrossRef]

26. Egelioğlu Cetişli N, Işık G, Özgüven Öztornacı B, Ardahan E, Özgürsoy Uran BN, Top ED, Ünsal Avdal E. Hemşirelik Öğrencilerinin Empati Düzeylerine Göre Kültürlerarası Duyarlılıkları. İzmir Katip Çelebi Üniversitesi Sağlık Bilimleri Derg 2016;1:27-33. https://dergipark. org.tr/tr/download/article-file/240076

27. Bekmezci H, Yurttaş Ç, Özkan H. Ebelik Bölümü Öğrencilerinin Empatik Eğilim Düzeylerinin Belirlenmesi. Sağlık Bil Derg 2015;2:46-54.

28. Atilla Gök G. Merhamet Etmenin Dayanılmaz Ağırlığı: Hemşirelerde Merhamet Yorgunluğu. Süleyman Demirel Üniversitesi İktisadi ve İdari Bilimler Fakültesi Derg 2015;20:299-313. https://pdfs.semanticscholar.org/14ec/ ddc2f64556bcde36c7a753fdca7fda2022c4.pdf

29. Eğlence $R$, Şimşek N. Hemşirelerin Maneviyat ve Manevi Bakım Hakkındaki Bilgilerinin Değerlendirilmesi. Acıbadem Üniversitesi Sağlık Bil Derg 2014;5;48-53. http://www.acibadem.dergisi.org/ uploads/pdf/pdf_AUD_227.pdf

30. Goleman, D. Sosyal Zeka İnsan İlişkilerinin Yeni Bilimi, 2. Baskı. İstanbul: Varlık; 2007.

31. Hiçdurmaz D, Arı İnci F. Eşduyum Yorgunluğu: Tanımı, Nedenleri ve Önlenmesi. Psikiyatride Güncel Yaklaşımlar 2013;7:295-303. [CrossRef]

32. Gentry JE, Baggerly J, Dunning K. The Accelerated Recovery Program For Compassion Fatigue. In: Figley CR, editor. Treating Compassion Fatigue. NY: Brunner/Mazel; 2002. p.123-62.

33. Ay V. Nietzsche'de'Merhamet'Kavramının Yeniden Değerlendirilmesi. Beytulhikme an International Journal of Philosophy 2013;3:199-215. https://dergipark.org.tr/en/download/article-file/40545 